\title{
ACCESSIBILITY OF DISTRICT HEALTH NURSING SERVICES IN THE GREATER BRONKHORSTSPRUIT
}

\section{Mrs EO Mashia}

MCur Graduate, University of Pretoria

Assistant director: Sub-directorate Youth Adolescent Health Department, Department of National Health

\section{Prof NC van Wyk}

PhD Nursing Science

Head, Department of Nursing Science, University of Pretoria

Corresponding author: nvanwyk@medic.up.ac.za

Key words: Geographic; functional; financial and cultural accessibility of health care services

\section{ABSTRACT}

A growing concern about the decline in the number of non-Black patients making use of the Bronkhorstspruit Clinic exists. The aim of the study was thus to determine the geographic, functional, financial and cultural accessibility of the health care service. A quantitative, descriptive study was conducted in the Greater Bronkhorstspruit (now referred as to as the Kungwini Local Municipality). The systematic random sample consisting of 260 respondents was drawn from Bronkhorstspruit, Zithobeni Township and Rethabiseng formal settlement. Sampling was done within a five-kilometer radius. Questionnaires were used as a method of data collection with the assistance of fieldworkers in Zithobeni and Rethabiseng. Postal questionnaires were used for Bronkhorstspruit, followed by reminder postcards. Fieldworkers followed up unreturned questionnaires. The study revealed that the health services were geographically accessible as 223 of the 253 households are located within a five-kilometer radius of the health facility. Clients, however, complained about the long waiting period for health care services. The health facilities were reported to be overcrowded and short of staff. The clients also indicated that there is a need for a 24-hour service in the area. Some clients highlighted that the health facility's opening and operating times are awkward. The health care services were financially accessible since they were provided free of charge across the board at Primary Health Care level. There was no doubt that the health services were culturally accessible in the sense that no complaints of racial discrimination were indicated. The clients did not have any problems to be nursed by health care providers of any cultural background.

The issue of functional accessibility needs urgent attention to be in line with the principle of Batho-Pele directed at the delivery of a customer-friendly service. For clients to be happy and encouraged to utilise the health services they should not be subjected to lengthy waiting periods in an overcrowded health facility. Health facilities should be properly staffed to enable health care providers to function and render efficient quality patient care.

\section{OPSOMMING}

Toenemende kommer bestaan oor die afname in die getal nie-Swart pasiënte wat van die Bronkhorstspruit Kliniek gebruik maak. Die doel van dié studie was om die geografiese, funksionele, finansiële en kulturele toeganklikheid van die gesondheidsdiens te bepaal. 'n Kwantitatiewe, beskrywende studie is in die Groter Bronkhorstspruit (tans bekend as die Kungwini Plaaslike Owerheid) gedoen. 'n Sistematiese ewekansige steekproef van 260 respondente is getrek wat Bronkhorstspruit, asook die Zithobeni- en Rethabiseng-woonareas inges/uit het. Respondente in ' $n$ vyf-kilometer-radius is ingesluit. Vraelyste is gebruik as metode om data in te samel. In die Zithobeni- en Rethabiseng-areas het veldwerkers met die voltooiing van die vraelyste gehelp. Die respondente van Bronkhorstspruit het hul vraelyste per pos ontvang. Dit is opgevolg met poskaarte waarin hulle aangemoedig is om die vraelyste in te vul. Veldwerkers het die respondente van Bronkhorstspruit wat nie 
gereageer het nie, opgevolg. Die studie het aangetoon dat die gesondheidsdienste geografies toeganklik is aangesien 223 van die 253 huishoudings binne ' $n$ vyf-kilometer-radius van die kliniek geleë is. Die kliënte het egter oor die lang wagtyd in die klinieke gekla. Die klinieke word deur kliënte oorstroom terwyl 'n personeeltekort ondervind word. Die respondente het ' $n$ behoefte aan ' $n$ 24-uur-diens in die area uitgewys. Hulle was van mening dat die tye waartydens die klinieke funksioneer nie voldoende is nie. Die gesondheidsdienste is finansiëel toeganklik aangesien alle Primêre Gesondheidsorg gratis gelewer word. Daar was ook geen twyfel by die respondente dat die gesondheidsdienste kultureel toeganklik is nie. Geen klagtes van rassediskriminasie is gerapporteer nie. Die kliënte vind dit nie onaanvaarbaar om deur 'n persoon van ' $n$ ander kulturele agtergrond behandel te word nie.

Die funksionele toeganklikheid van die gesondheidsdienste benodig onmiddellike aandag om dit in ooreenstemming met die beginsel van Batho-Pele, wat gerig is op die lewering van kliëntvriendelike diens, te bring. Om die kliënte gelukkig te hou en aan te moedig om die klinieke te gebruik, behoort hulle nie blootgestel te word aan lang wagtye in oorvol klinieke nie. Die gesondheidsdienste behoort van voldoende personeel voorsien te word, sodat pasiënte effektief versorg kan word.

\section{INTRODUCTION}

The South African health system is facing a challenge to be part of the comprehensive programme aimed at redressing previous social and economic injustices. The South African Government showed their commitment to implement the Reconstruction and Development Programme and to develop a district health system based on the Primary Health Care Approach as declared at Alma-Ata in 1978. District-based health services have worked well in many countries and have adapted to various situations, from developing countries on our continent to sophisticated systems (Department of Health South Africa, 1995:1).

For the district health system to be properly established, it must have effective health services that meet the needs of the communities they serve in a fast, equitable, available and accessible manner. The health workers should be friendly and courteous (Harrison, 1997:7).

\section{PROBLEM STATEMENT}

Since 1994 the health services of Greater Bronkhorstspruit (now the Kungwini Local Municipality) render a free service to the community in the vicinity of Bronkhorstspruit and surrounding farm areas, irrespective of race and colour. The service includes preventative health care and curative services according to the primary health care approach.

A decline in the number of patients (other than black patients) making use of these services was evident when looking at the Bronkhorstspruit Clinic statistics for 1995 and 1999. In 1995, 1755 White, 56 Coloured, 39 Indian, 24 Chinese and 6812 Black patients used the service. In 1999, 756 White, 58 Coloured, seven Indian, two Chinese and 11227 Black patients used the service (Bronkhorstspruit Clinic Statistics for 1999).

According to the Policy Document for the Development of District Health Services (Department of Health, 1995:69) accessibility of the service determines the use of the service. Accessibility is determined by geographic, financial and functional factors, including the distance from the facility, the affordability of the service and the attitudes of health workers.

\section{RESEARCH QUESTION}

Is the health services utilised with ease as far as the distance from the facility, affordability of services and attitudes of health workers are concerned?

\section{AIM OF THE STUDY}

The aim of the study is to determine the geographic, functional, financial and cultural accessibility of the health care services.

\section{LITERATURE REVIEW}

Community members should be able to gain access to health care services irrespective of their cultural background, ethnic grouping or social standing. Various factors determine whether a service is accessible to the people of the community, including geographic, 
functional, financial and cultural factors.

\section{Accessibility}

Accessibility is "the continued organized supply of an equitable level of health care that is easily reachable for all citizens, be it in geographical, functional, financial and cultural terms" (Department of Health, 1992:2). This means that regular health care should be provided at all health care facilities at all times. Services should be near the community and rendered at a price they can afford.

Dyck (1996:543) defines access as approachability and ease of contact. Further, the accessibility of services should be measured in terms of the hours when clients are able to access health care services. McGuire, Gerber and Clemen-Stone (1996:220) add that the nurse must understand the client's needs before she/he can determine whether resources are accessible to the client.

Accessibility can be subdivided into the following factors: geographical, functional, financial and cultural.

\section{Geographic accessibility}

Geographic accessibility encompasses the acceptable distance, travelling time and means of transport available to reach the health care services in the community (Department of Health, 1992:2). According to Poland, Taylor and Hayes (1990:17), geographic accessibility encompasses distance, topography and the mode of transport used to reach the health facility.

Although geographic accessibility is usually measured in terms of distance (Vos, Borgdorf \& Kachidza, $1990: 1027)$ the area and the population density of the area have to be considered too. Poland et al. $(1990: 17)$ indicate that the distance from the central location to the nearest fixed health care facility is measured in terms of kilometers and ease of access to that facility. People living more than eight kilometers from a static clinic and more than three kilometers from a mobile clinic site have poor access to health care. A lack of transport as is the case in many developing countries contributes to the problems that people may experience to make use of health care services (Garrett, 1995:32). According to Giambruno, Cowell, Barber-Madden and Mauro-Bracken (1997:104) transportation relates not only to the availability thereof, but also to the costs. Although health care services may be free of charge, making use of the service may still be costly. This in turn determines the geographical accessibility of the health service.

\section{Functional accessibility}

Functional accessibility refers to the appropriate type of care made available to those individuals who need it when necessary. It means properly trained personnel provide all types of care according to the Primary Health Care Package (Department of Health, 1992:2). The services clients use differ, depending on their socio-economic status. High socio-economic status clients attend preventative health care services more often than people from low socio-economic status. The latter however, make use of services where all their health care needs can be attended to (Bailey \& Phillip, 1990:10).

Casey, Wellever and Moscovice (1997:33) indicate that a minimum set of health care services must, however, be available within certain distances. This will improve utilisation of health care by imposing network requirements that ensure the provision of basic health services. It would be ideal if clients can receive comprehensive health services at their nearest clinics. Clinics should be more efficiently organised and functionally integrated to render curative and preventative services (London \& Bachman, 1997:35).

It is necessary to consult the community to determine the most appropriate hours of operation for the health care facility. The community wants a flexible way of working in order to enable them to access the health care services maximally (Dale, Shipman, Lacock \& Davies, 1996:1209). In addition to convenient hours of operating, the attractiveness of the clinic environment, location of the health facility and the time spent when visiting the health service determine the accessibility of the health service (York, Grant, Gibeau, Beecham \& Kessler, 1996:284).

As waiting time is considered as a parameter for the quality of health care service, it is unacceptable that clients have to wait long periods in clinics. Kaplan, Brindis, Phibbs, Mellinkovisch, Naylor and Alhstrand (1999:242) support this perspective by stating that appointments must be quickly obtained and a fast effi- 
cient service must be guaranteed at all times.

\section{Financial accessibility}

Financial accessibility refers to the affordability of the services for the community and the state. If a service is financially accessible, health care consumers can pay for it or be subsidised by the government (Department of Health, 1992:2). According to Dreyer, Hattingh and Lock (1993:162) financial accessibility refers to the ability of individuals to pay for the health care services they receive.

Garrett (1995:31) indicates that some clients from rural areas have multiple low-paying jobs and do not generate sufficient income to support their families and do not qualify for medical insurance. They end up receiving health care from overcrowded communitybased clinics, thus adding to the difficulties to access health services.

Financial accessibility is, however, a relative concept as people are willing to pay more if they have confidence in the quality of the service (Dyck, 1996:541). According to Kaplan et al. (1999:38), improved health care access can be achieved by reducing structural barriers like lowering the costs of primary health care while expensive tertiary health care costs are restricted.

\section{Cultural accessibility}

There is limited literature on cultural accessibility, however, according to Dreyer et al. (1993:162), cultural accessibility relates to the acceptability of services provided to the community. In the context of this study, it refers to the attitudes of the health workers and the degree to which the health workers are capable of rendering services according to the needs of the relevant community.

A partnership between community representatives and staff from the health care services can contribute to the creation of a caring atmosphere in the clinic that enhances cultural accessibility of the services rendered (Beecham \& Wilson-Barnett, 1995:684).

Cultural differences coupled with associated communication difficulties may lead to confusion and the development of poor relationships between health workers and patients. Cultural mismatches can give inaccurate results due to assessments that are not culturally appropriate. Barrio (2000:880) agrees that families from certain cultural groups experience several barriers when they utilise health care services. The stigma attached to certain health conditions gave rise to the problem that members from different cultural groups were reluctant to seek help outside their immediate families.

The acceptance of the cultural orientation of a patient is vital in service delivery and should therefore be respected. Failure to do so can have adverse effects on the acceptability of the service and has to be avoided by all means (Webb, 1996:264). Health workers that disregard clients' needs based on their ethnicity and make inappropriate assumptions about clients' needs are not rendering a cultural congruent health care service.

\section{RESEARCH DESIGN AND METHOD- OLOGY}

A quantitative, descriptive approach was used to gather information about the accessibility of the District Health Services of Bronkhorstspruit. The population consists of the residents of the Greater Bronkhorstspruit area (now part of the Kungwini region). Households of three specific regions of Greater Bronkhorstspruit were targeted, namely Bronkhorstspruit, Zithobeni and Rethabiseng (Refer to Table 1).

Table 1: The study population and sample size

\begin{tabular}{|l|l|l|l|}
\hline AREA & HOUSEHOLDS & SAMPLE SIZE & RACE \\
\hline Bronkhorstspruit & 1916 & 110 & Mixed \\
\hline Zithobeni & 2197 & 130 & Black \\
\hline Rethabiseng & 1321 & 80 & Black \\
\hline Total & 5434 & 320 & \\
\hline
\end{tabular}


A systematic sampling method was chosen where every $17^{\text {th }}$ house or stand was selected to participate in this study. From the study population (5 434 households) 320 were included in the sample. All the households from Zithobeni (130 households) and Rethabiseng ( 80 households) are black, while the 110 households from Bronkhorstspruit are mixed. The head of the households completed the questionnaires on behalf of the family.

\section{The questionnaire as a research tool}

The questionnaire was developed after a comprehensive literature study of the factors that determine accessibility of health services. The questionnaire was based on the research question and the aim of the study.

The questionnaire had 31 items. Seven questions were dichotomous, two were matrix type, 19 were multiple-choice and three were open-ended. Twentyeight items in the questionnaire required respondents to select their responses from provided alternatives, and three items allowed respondents to provide their own answers. Afrikaans and English versions of the questionnaire were used.

\section{Reliability and validity}

The reliability of the questionnaire was tested in all three areas by taking a ten percent sample from the target population, using the predetermined methods of sampling. The sample used in the pilot study was not included in the major study. The results did not differ in any way from the major study.

To ensure that information was collected reliably, the field workers were trained to give them common understanding. Their roles and responsibilities were clearly explained as far as completing the questionnaire was concerned. All the questions were explained and simplified to the field workers. Exercises were done with the field workers to practice completing the questionnaires to ensure they understand their tasks and roles. Field workers were not supposed to interview the respondents. Their responsibility was to read the questions to the respondents and tick the given responses.
To ensure content validity, an extensive literature study about the topic was done. A statistician determined the sample size, and scrutinised and modified the questionnaire to be acceptable for data analysis. The questionnaire was edited for accurate translation from English to Afrikaans, to ensure accurate and similar information from all respondents.

\section{Ethical considerations}

Questionnaires for each area were colour coded and given a serial number to ensure that all the questionnaires were returned. Partial anonymity was maintained with the mailed questionnaires: surnames were acquired from the local municipality for addressing the envelopes. Total confidentiality with the findings of the research was maintained. Permission to conduct the research was sought from the Ethical Committee of the Faculty of Health Sciences, University of Pretoria and from the Chief Executive Officer of the Bronkhorstspruit Municipality. Cover letters were attached to each questionnaire, explaining the purpose of the study and the rights of the respondents as voluntary participants.

\section{Research setting}

The research was conducted at the Greater Bronkhorstspruit (now Kungwini Local Municipality). The respondents were visited at home to complete the questionnaire. The respondents included residents of Bronkhorstspruit, Zithobeni location and Rethabiseng formal settlement.

\section{DATA ANALYSIS AND FINDINGS}

Of the 320 respondents targeted, a total of 260 responded and returned the questionnaires. A computer was used to analyse the data obtained. Only three questions were open-ended and the researchers manually analysed those responses. The respondents were visited at their homes to get hold of those that did not utilise the health services. The head of the households completed the questionnaires on behalf of the family.

Area of residence: The majority of 217 (83.7\%) respondents were from the township and formal settlement, namely Zithobeni and Rethabiseng. 
Level of education: Although members of 15 households $(30,6 \%)$ in the Bronkhorstspruit area had tertiary education, 166 (63.8\%) out of the 260 households, were without any education.

Employment status: The aim was to identify the number of households that were able to afford to pay for any kind of health care service, or the means of transport to the health care facility, therefore the employment status of the head of each household was assessed. In Rethabiseng, 42 (53,2\%) of the respondents were unemployed. Twenty-nine $(36,7 \%)$ respondents were unskilled, six $(7,59 \%)$ were skilled, one $(1,27 \%)$ was professional and one $(1,27 \%)$ was selfemployed. In Zithobeni, six (4,6\%) respondents were unemployed, 42 (32,1\%) were unskilled, 64 (48,85\%) were skilled, seven $(5,34 \%)$ were professional and 12 $(9,16 \%)$ were self-employed. It was found that there was a high level of unemployment in Rethabiseng (refer to Figure 1).

Age breakdown: A large percentage of households $(73,5 \%)$ have teenagers in the Greater Bronkhorstspruit.

Language spoken: Bronkhorstspruit predominantly consisted of Afrikaans-speaking people. In Rethabiseng and Zithobeni, Northern-Sotho and Ndebele were commonly spoken languages.
Kilometers travelled to the health facility: Of the 253 households represented, 223 (88.93\%) were located within a five-kilometer radius of the health facility. Some preferred to travel to the clinic in town, which was within an eight- to sixteen-kilometer radius from Rethabiseng and Zithobeni respectively (refer to Figure 2).

Method of transport used: In Bronkhorstspruit, 83,7 per cent of households used private transport to travel to the health care facility, while 9,9 per cent of households in Zithobeni used private transport to travel to the health care facility.

Type of District Health Nursing Services preferred: Respondents were asked to indicate what type of health care services they made use of, either public or private. Most Black respondents made use of public health services. White respondents preferred private health services. This was possibly because the White community could afford to pay for private health services (refer to Table 2).

Hours of operation: Overall findings were that 143 $(57 \%)$ respondents indicated that the health care facilities are open for six to eight hours a day. There was inconsistency from the township respondents. Different opening and closing times were reported, despite the fact that respondents stayed in the same place.

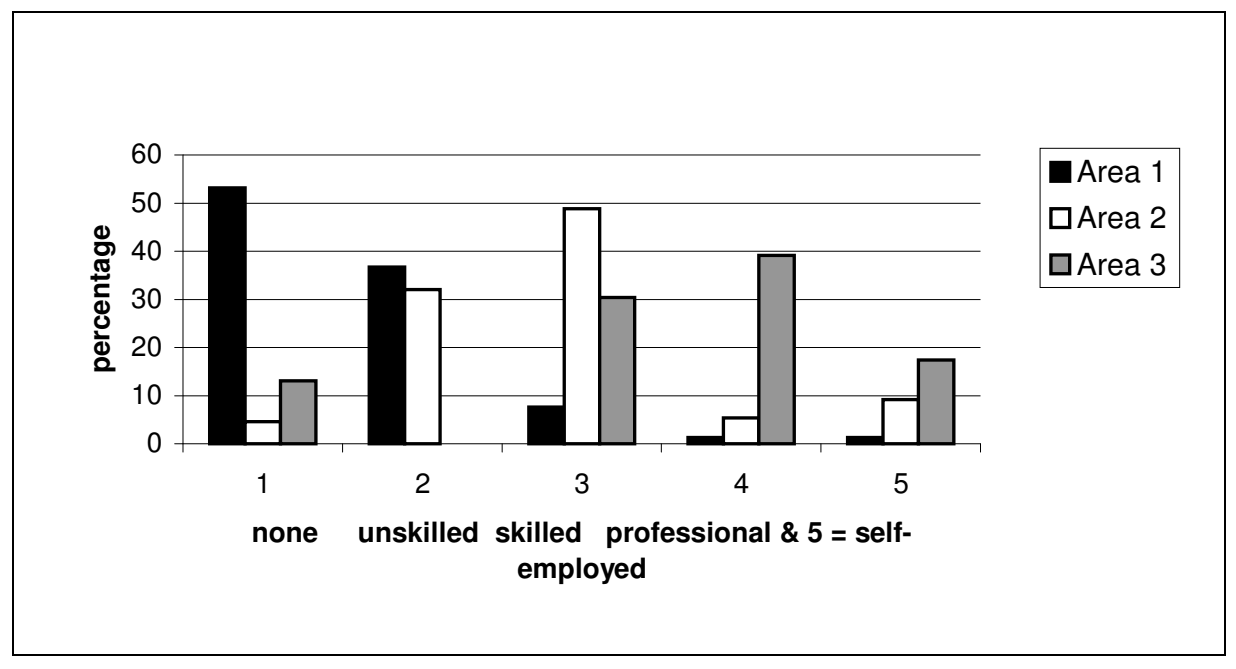

Area 1: Rethabiseng

Area 2: Zithobeni

Area 3: Bronkhorstspruit

Figure 1: Employment status 


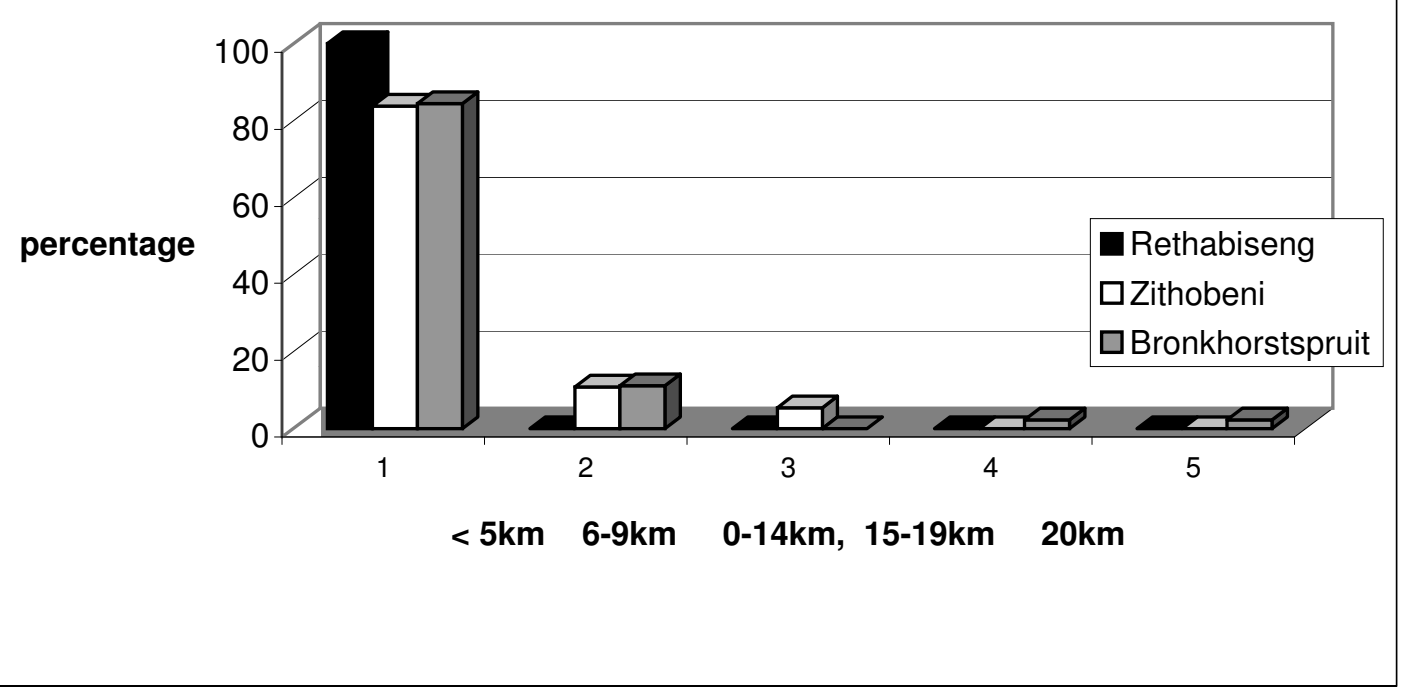

Figure 2: Kilometres travelled

Services mostly utilised: Findings revealed that the following services are utilised most often:

- Treatment of minor ailments

- Family planning services

- General child health care and immunisation

- Antenatal and postnatal services.

The Bronkhorstspruit town residents utilise all health programmes minimally except for treatment of minor ailments.

\section{Respondents' dislike about the health services:} Findings showed that the majority of respondents in Rethabiseng, Zithobeni and Bronkhorstspruit were not happy about the hours of service, waiting periods and availability of medications.

Likes about the health services: The majority of respondents in Rethabiseng (76\%) and Zithobeni $(67,2 \%)$ reflected their satisfaction with the friendliness of the staff. Eighty percent of the respondents in Rethabiseng and ninety-two percent of the respondents in Zithobeni appreciated the cleanliness of the clinic. Eighty-seven percent of the respondents in Bronkhorstspruit were satisfied with the health information and the availability of medication.

Availability of help when needed: The findings showed that the availability of health care services is mediocre. Respondents reported that they sometimes or seldom received assistance immediately when needed.

Areas where changes are expected: The respondents from all three areas in the study indicated that they would like to see improvements with regard to the waiting period at the clinics. The waiting area was not up to standard.

Notification of the person in charge about the problems experienced: Most respondents did not notify the person in charge at the clinic about problems experienced at the health care facilities. Only $35(14,5 \%)$ of the respondents indicated that they communicated with responsible staff about the problems that they have experienced.

Table 2: District Health Nursing Service preferences

\begin{tabular}{|l|l|l|l|l|}
\hline TYPE & RETHABISENG & ZITHOBENI & BH/SPRUIT & TOTAL \\
\hline PUBLIC CLINIC & $68(86 \%)$ & $109(83 \%)$ & $13(28 \%)$ & $190(73,9 \%)$ \\
\hline PRIVATE CLINIC & $11(13,9 \%)$ & $22(16,8 \%)$ & $33(70,2 \%)$ & $66(25,7 \%)$ \\
\hline OTHER & $0(0 \%)$ & $0(0 \%)$ & $1(2,1 \%)$ & $1(0,4 \%)$ \\
\hline TOTAL & $79(100 \%)$ & $131(100 \%)$ & $47(100 \%)$ & $247(100 \%)$ \\
\hline
\end{tabular}


Methods to notify or lodge complaints: The majority of the patients who complained did it verbally. Only four people made use of a suggestion box.

Visiting clinic of choice: A significant number of respondents indicated that, if they had a choice, they would prefer to visit other health care facilities (refer to Figure 3).

Reasons for not seeking alternative health services: The findings revealed that 167 respondents $(64,5 \%)$ had no choice due to a lack of money. One hundred and twenty-eight respondents $(49,4 \%)$ did not have medical aid, 116 respondents $(44,8 \%)$ did not have their own transport and 93 respondents $(35,9 \%)$ lacked an alternative health care facility.

Involvement in issues that affect own health: The findings indicated that 138 respondents $(53,3 \%)$ used personal confrontation to raise complaints about their own health issues. The community forum and leaders were minimally used to address issues. This is a barrier to effective health service provision, because avenues of reporting are not utilised.

Comments about health services: The top five complaints from Rethabiseng and Zithobeni were ranked as follows:

1. Waiting period/Operating hours

2. Clinic structure/waiting area

3. Shortage of staff
4. Extension of operation hours

5. The availability of medication

The respondents in Bronkhorstspruit (a predominantly White area) raised their concerns, but they were slightly different from those in Rethabiseng and Zithobeni. Their concerns were as follows:

1. The health care facility always overcrowded

2. Health care services could improve

3. Waiting hours were very long

4. They got good service at least once

5. Poor service.

Findings revealed that the health care services are overcrowded and short-staffed. Despite these shortcomings, the communities utilise the health services with the hope that it will improve.

Payment for services: Some of the respondents strongly felt that a paid service would be better than a free service (refer to Figure 4).

Suggested fee for service: In Rethabiseng 49 respondents $(69 \%)$ and in Zithobeni 58 (45,3\%) respondents preferred free health care services. In Bronkhorstspruit 19 respondents $(43,2 \%)$ felt health services should be paid for (between R11.00 and R20.00). Ten respondents (22.7\%) from Bronkhorstspruit suggested a R1.00 to R5.00 fee. In Zithobeni, 31 respondents (24,2\%) cited a fee of $R 1.00$ to $R 5.00$ and 21 respondents (16.4\%) felt that a fee of $R 6.00$ to $R 10.00$ is suitable.

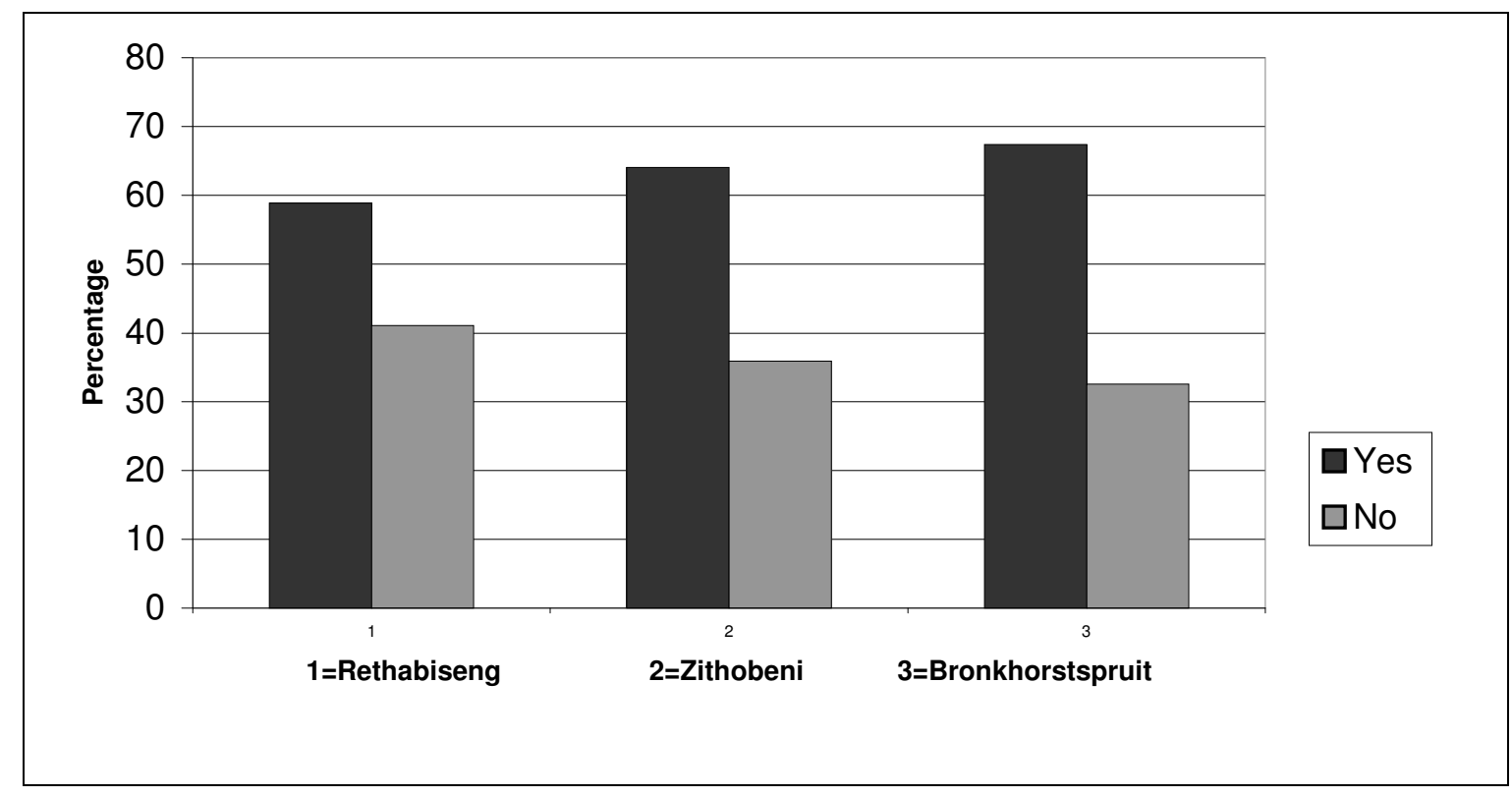

Figure 3: Opinion of choice for health services 


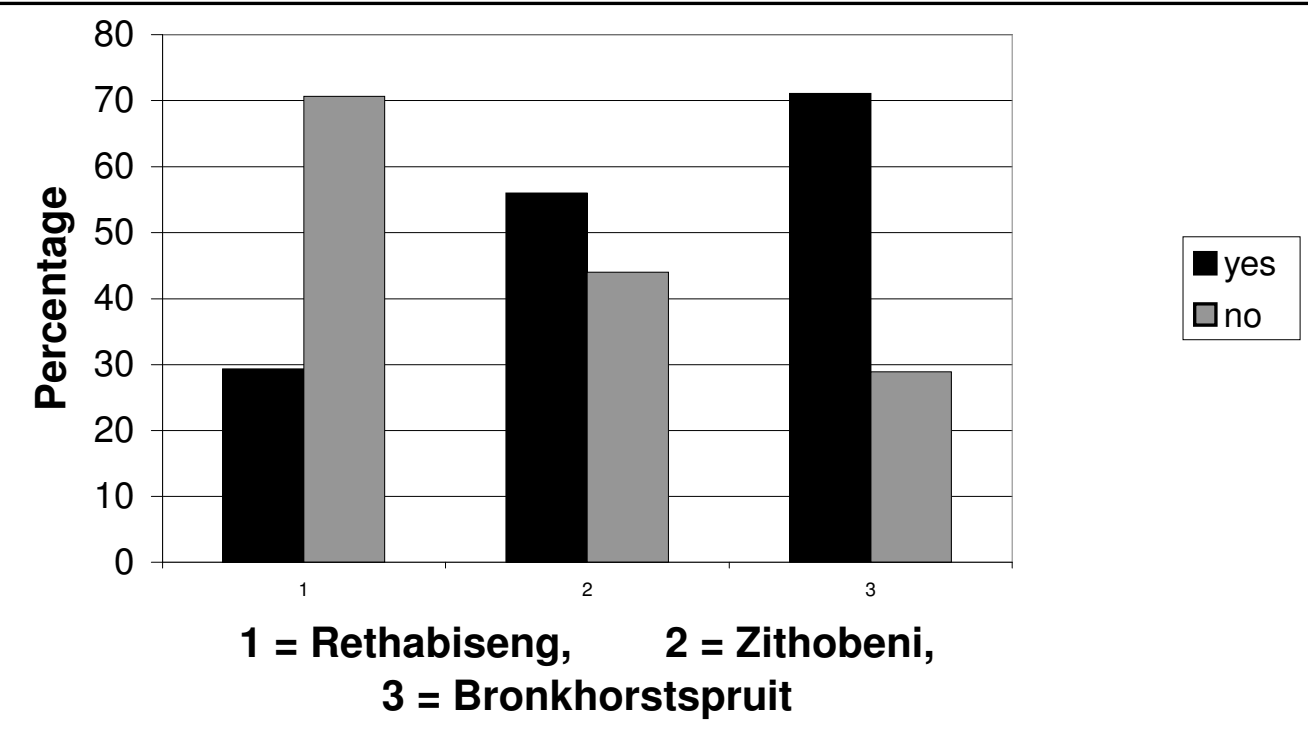

Figure 4: Choice to pay a fee for health services

Area of choice: Out of 246 participants who responded, $237(96,3 \%)$ indicated that they would prefer to attend health care services in an area of their choice; nine respondents $(3,7 \%)$ had no preference.

Receiving health care from a health worker of a different cultural background: Most respondents, a majority of $223(89.56 \%)$, replied that they did not have a problem with receiving health care from staff with a different cultural background.

\section{SUMMARY OF FINDINGS}

\section{Geographic accessibility}

The health services are within reach and the community has ample opportunity to use it. The health services are strategically situated to allow the community to access it. More than $80 \%$ of the respondents live within a five-kilometer radius of the health facility. The respondents indicated that they either used public or private transport or walked to the health facility.

The area in which a health facility is situated, the distance travelled and the method of transport used to reach the health facility contribute to the geographic accessibility of a health facility. Therefore the assumption can be made that the services in the Greater Bronkhorstspruit are geographically accessible.

\section{Functional accessibility}

The majority of the clients do appreciate the health services rendered at all three areas; they also gave room for improvement wherever the shortcomings had been identified. Clients are forced to accept and use what is available due to a lack of variety of alternative health services.

The long waiting period is a cause for concern; it is a general problem at all public health facilities in the three areas. The staff's attitudes were not highlighted as a problem towards service delivery.

\section{Financial accessibility}

The higher the level of education, the better the community understands the importance of health care and the more willing they become to pay for the health care services received.

The people from the higher socio-economic group can afford private transport to visit health services and also have medical aids to pay for their private health services.

The District Health Services are affordable because the clients are able to utilise the health services free 
of charge and the government subsidises the public health services at primary level.

\section{Cultural accessibility}

There are no clear lines of communication between the service users and caregivers. The Greater Bronkhorstspruit is composed of diverse cultural groups. The health workers serve them equally with due respect, making the health services user-friendly and culturally accessible.

\section{LIMITATIONS OF THE STUDY}

The study was limited to the investigation of the accessibility of the service only. Complaints about the service were thus listed. A follow-up study to explore ways to address the complaints is recommended. The following recommendations serve as guidelines.

\section{RECOMMENDATIONS}

An appointment system must be introduced to regulate the flow of clients. Even those who have limited time to wait for a service should be accommodated; these are clients who use their lunch times to attend the health facility, hoping to receive assistance within a short period of time Specific health workers should be allocated daily to assist clients in the fast queue.

The fast queue is a service for clients who do not need personal consultation. This service must be effectively implemented to assist clients who come for follow-up services or for the collection of medication.

The health services of Greater Bronkhorstspruit should be improved and marketed widely to attract more public health service users. Firstly the Local Municipality, Health Services Management should address the identified problems to assist the health care givers to improve the quality of health care. High standards of health care can be achieved by provision of the human and financial resources.

All the nurses should be trained in physical assessment and treatment of patients. The majority of clients visit the clinics for treatment of minor ailments. should be trained in customer care to provide improved customer services. Clients meet with the clerical staff before the nurses attend to them. The first impressions and attitudes have an impact on the health care users towards the health services rendered at a specific health facility.

Management should recruit additional personnel as determined by the health care needs of the community at a particular health facility. The problem of long waiting hours will not be addressed as long as there is a shortage of staff. The health facility should be staffed according to the number of patients that have to be attended to.

The health facility waiting areas in Zithobeni and Rethabiseng should be extended since most of the respondents reiterated that these facilities are very small and that there is not enough space.

Arrangements must be made to implement extended hours of health services as suggested by the respondents. This measure will assist to accommodate the clients who are unable to visit the health services during office hours due to some commitments. It will also reduce the overcrowding of services caused by the influx of clients who arrive early in the morning to ensure that they will get treatment.

The health care workers should motivate the local authority to elect clinic committees in order to open lines of communication between the community and the health care givers. This will form a platform to bring up all the complaints and ideas to improve service delivery.

The District Health Nursing Services should remain free of charge but means to prevent abuse of health service could be initiated. The community should be educated on cost-effectiveness of the health services.

The budget of health services should be costed per facility to evaluate and monitor the funds utilised towards individual patient care. Facility managers should be involved in financial management of their respective health facilities for financial accounting at unit level.

\section{CONCLUSION}

The non-nursing personnel of the health care facilities 
Health service users (especially the white cultural group) are discouraged by the long waiting periods and the hours of service (clinics open at 8:00 and close at 16:00). If staff shortages can be addressed, the flow of patients will improve, thereby shortening the waiting period. Shorter waiting periods may attract even the white cultural group to utilise all the health programmes in the District Health Nursing Services.

\section{LIST OF SOURCES}

BAILEY, W \& PHILLIP, DR 1990: Spatial patterns of use of health services in Kingston Metropolitan Area, Jamaica. Social Science Medicine, 30(1):1-12.

BARRIO, C 2000: The cultural relevance of community support programs. Psychiatric Services, 51(7):879-883.

BEECHAM, H \& WILSON-BARNETT, J 1995: HIV/AIDS: Consumers' views on needs and Services. Journal of Advanced Nursing, 22:677-686.

BRONKHORSTSPRUIT CLINIC STATISTICS for 1999.

Bronkhorstspruit: Bronkhorstspruit Local Authority.

CARSEY, MM, WELLEVER, A \& MOSCOVICE, I 1997: Rural health network development: Public policy issues and state initiatives. Journal of health Politics, Policy and Law, 22(1):23-45.

DALE, J; SHIPMAN, C; LACOCK, L \& DAVIES, M 1996: Creating a shared vision of out of hours care: Using rapid appraisal method to create an interagency community oriented approach to service development. British Medical Journal, 312:1206-1210.

DEPARTMENT OF HEALTH 1992: Strategy for Primary Health Care in South Africa. Pretoria: Government Printers.

DEPARTMENT OF HEALTH 1995: Policy document for Development of District Health Systems for South Africa. Pretoria: Government Printers.

DREYER, M, HATTINGH, S \& LOCK, M 1993: Fundamental aspects in community health nursing: Community health care in Southern Africa. Pretoria: Southern.

DYCK, D 1996: Gap analysis of health services: Client survey. AAOHN Journal, 44(11):541-549.

GARRETT, DK 1995: Mobile access: Opening health care doors. Nursing Management, 26 (10):29-33.

GIAMBRUNO, C; COWELL, C; BARBER-MADDEN, R \& MAUROBRACKEN 1997: The extent of barriers and linkages to health care for headstart children. Journal of Community Health, 22(2):101-113.

HARRISON, D 1997: A pocket guide to District Health Care in South Africa. Durban: Kwik Kopy.

KAPLAN, DW; BRINDIS, CD; PHIBBS, SL; MELLINKOVISCH, P; NAYLOR, K \& ALHSTRAND, K 1999: A comparison study of an elementary school based health center: Effect on health care access and use. Archives Pediatric Adolescent Medicine, 153:235242.

LONDON, L \& BACHMAN, OM 1997: Pediatric utilization of a teaching hospital and a community health center. Predictors of level of care used by children from Khayelitsha, Cape Town. South African Medical Journal, 87(1):31-36.

McGUIRE, SL, GERBER, DE, CLEMEN- STONE, S 1996: Meeting diverse needs of the clients in the community: Effective use of the referral process. Nursing Outlook, 44: 218-222.

POLAND, BD; TAYLOR, SM \& HAYES, MV 1990: The ecology of health services' utilization in Grenada, West Indies. Social Science Medicine, 30(1):13-24.

VOS, J; BORGDORFF, MW \& KACHIDZA, EG 1990: Cost and output of mobile clinics in a commercial farming area in Zimbabwe. Social Science Medical Journal, 31(11):1207-1211.

WEBB, E 1996: Meeting the needs of the minority ethnic communities. Archives of Diseases in Childhood, 74:264-267.

YORK, R; GRANT, C; GIBEAU, A; BEECHAM, J \& KESSLER, J 1996: A review of problems of universal access to prenatal care. Nursing Clinics in North America, 31(2):279-291. 